\title{
Kernos
}

Revue internationale et pluridisciplinaire de religion grecque antique

5 | 1992

Varia

\section{Roland CRAHAY, La religion des Grecs}

Pierre Somville

\section{(2) OpenEdition \\ Journals}

Édition électronique

URL : http://journals.openedition.org/kernos/1074

DOI : $10.4000 /$ kernos. 1074

ISSN : 2034-7871

Éditeur

Centre international d'étude de la religion grecque antique

Édition imprimée

Date de publication : 1 janvier 1992

ISSN : 0776-3824

\section{Référence électronique}

Pierre Somville, "Roland crahay, La religion des Grecs », Kernos [En ligne], 5| 1992, mis en ligne le 19 avril 2011, consulté le 24 septembre 2020. URL : http://journals.openedition.org/kernos/1074 ; DOI : https://doi.org/10.4000/kernos.1074 
Roland CRAHAY, La religion des Grecs, Bruxelles, Éd. Complexe, 1991, 1 vol. $11,5 \times 17,5 \mathrm{~cm}, 180 \mathrm{p}$.

Cet ouvrage est la réédition du petit livre publié voici 25 ans dans la collection «Problèmes» chez Labor. On y retrouve, mise à jour et plus agréablement présentée 1 , la même anthologie raisonnée où prennent place les plus grands textes de la tradition religieuse. D'Homère à Dion Chrysostome et à Grégroire de Naziance, en passant par Hérodote, Platon, Démosthène, Euripide, les Orphiques, etc., nous voyons s'édifier sous nos yeux tout un corpus, bien connu en ces textes, lui servant de matériaux, mais saisissant de clarté par l'ordonnance et la composition.

Rien n'y est négligé du sentiment religieux, des phénomènes de croyance, - populaire ou littéraire, - des rites, des comportements sociaux, majoritaires ou non. Peut-être les lieux de culte sont-ils quelque peu oubliés, mais il suffira à cet effet de se reporter à l'ouvrage de Marie Delcourt, Les grands sanctuaires de la Grèce antique, récemment réédité par Gérard Monfort (1982). Rappelons que Roland Crahay fut son élève, et que c'est à elle qu'il emprunte sa traduction des textes d'Euripide; tous les autres extraits ont fait l'objet d'une version française originale, neuve et irréprochable.

Pierre SOMVILLE (Liège)

L.P. GERSON, God and Greek Philosophy. Studies in Early History of Natural Theology, London-New York, Routledge, 1990, 1 vol. 14 x $22 \mathrm{~cm}$, 340 p. (Issues in Ancient Philosophy, gen. ed. M. Schofield)

Cet ouvrage est une manifestation typique de l'esprit analytique de la recherche anglo-saxonne. Il se divise en cinq chapitres, traitant successivement des "origines présocratiques de la théologie de la nature» (p. 1-32), de «Platon sur dieu et les formes» (p. 33-81), du "dieu mouvement d'Aristote» (p. 82-141), de "la théologie matérialiste stoïcienne" (p. 142-184) et de "Plotin sur dieu au-delà de dieu» (p. 185226). Bien qu'on puisse regretter l'absence de présentation de la sophistique, on se réjouira des réflexions de l'A. commençant par l'analyse de la notion d'«archè» (p. 5-14), pour aboutir à la relation étroite entre l'Un, archè de tout, et le "nous» (p. 221-238). Parmi les chapitres intéressant l'historien de la religion, on mentionnera ceux sur la forme du dieu chez Platon (p. 57-66), sur le rapport entre dieu, causalité et être chez Aristote (p. 134-141) et sur les arguments des Stoïciens concernant l'existence de dieu (p. 154-167). L'A. aborde également la question de

1 Petite remarque iconographique : le «Zeus» en p. 1 de couverture pourrait bien être un Poseidon .... 